\title{
PROBLEMS IN CRITICAL CARE NURSE-PATIENT COMMUNICATION: EXAMPLES OF POLAND AND TURKEY
}

\author{
Yesim Yaman $\mathrm{Aktas}^{1}$, Małgorzata Nagórska ${ }^{2}$ and Neziha Karabulut ${ }^{3}$ \\ ${ }^{1}$ Department of Surgical Nursing, Faculty of Health Sciences, Giresun University, Giresun, Turkey; \\ ${ }^{2}$ Institute of Nursing and Health Sciences, Rzeszow University, Rzeszow, Poland; \\ ${ }^{3}$ Faculty of Health Sciences, Ataturk University, Erzurum, Turkey
}

\begin{abstract}
SUMMARY - The aim of this study was to determine the problems related to nurse-patient communication in the intensive care unit (ICU), with a focus on differences between Poland and Turkey. A descriptive survey design was used. The study was conducted in Surgical ICU, Lwowska Hospital in Poland and ICU, Training and Research Hospital in Turkey. Fifty critical care nurses in Poland and 52 critical care nurses in Turkey were included in the study. Patient data were collected using a questionnaire that was prepared by the researchers. In this study, $46 \%$ and $42.3 \%$ of the nurses reported they had communication problems with patients in Poland and Turkey, respectively. It was also found that the nurses in Poland mostly used therapeutic touch for non-verbal communication (80\%), whereas the nurses in Turkey used facial expression (90.4\%). Critical care nurses in both countries experienced similar difficulties in patient communication. It is recommended that the patient to nurse ratio in ICUs be planned according to the intensive care standards.
\end{abstract}

Key words: Intensive care units; Nurse-patient relations; Communication

\section{Introduction}

As a direct result of critical illness and its management, intensive care unit (ICU) patients and their caretakers are vulnerable to communication breakdown and associated adverse sequels. Nurses are the most frequent communication partners of critically ill patients during the periods when patients are unable to speak ${ }^{1}$. Endotracheal intubation, time-critical actions and noisy work environments do not provide a setting that is conducive to clear communication ${ }^{2}$. However, nurses do not typically receive training in communication assessment or specialized techniques to use with non-speaking patients. Rather, ICU nurses report learning how to communicate with intubated patients through trial and error, and by observing others ${ }^{1,3}$.

Correspondence to: Neziha Karabulut, $R N, P h D$, Faculty of Health Sciences, Ataturk University, 25030 Erzurum, Turkey

E-mail: nezihekarabulut@hotmail.com

Received December 12, 2016, accepted March 15, 2017
Communication means simultaneously talking and/or signaling non-verbally, listening and/or observing non-verbal signals, thinking, interacting, planning and responding $g^{4}$. Oral communication is generally an important part of communication, and the more congruence there is between verbal and non-verbal communication, the more accurately messages will be interpreted or understood ${ }^{5}$. However, in many ICU circumstances, verbal communication plays a minimized role. Non-verbal signaling is often the primary method of conveying messages, a difficult barrier for critical care patients to communicating their needs ${ }^{2,3,6}$.

Nurses report feeling frustrated by communication difficulties and admit avoiding patients with whom communication is difficult ${ }^{3,7,8}$. Interpreting patients' communication attempts may not be prioritized in ICUs, where management of complex medical equipment and delivery of life-sustaining treatment takes precedence. Communication exchanges are often limited to brief task or procedure-related statements initi- 
ated and controlled by the nurse or healthcare provid$\mathrm{er}^{9,10}$. Such one-sided communication thwarts patient messages, excludes the patient from treatment decision-making, and leads to patient distress, frustration, loss of sense of control, and withdrawal ${ }^{11,12}$. According to Russell, the lack of ability to communicate with care providers during the periods of mechanical ventilation in an ICU not only causes anxiety but also contributes to less than optimal recovery after discharge ${ }^{13}$.

Therefore, it is important to know the barriers to and the effects of ICU nurse-patient communication in order to prevent the problems experienced by both caregiver and recipient. The specific aims of this study were to determine:

- which problems related to patient communication do critical care nurses have?

- what are differences between Poland and Turkey regarding patient communication problems?

\section{Materials and Methods}

\section{Design and sampling}

A descriptive survey design was used to determine nurses' problems related to patient communication in the ICU. The study also explored differences between Polish and Turkish ICU nurse-patient communication. In this study, sampling was not used and instead all nurses that agreed to participate were included in the study. However, 25 and 37 nurses refused to participate in the study in Poland and Turkey, respectively. Fifty ICU nurses at Lwowska Hospital, Poland and 52 ICU nurses working in surgical ICUs at Training and Research Hospital in Erzurum, Turkey, were enrolled in the study.

\section{Ethical considerations}

The study was approved by the Ethics Committee of the Health Sciences Institution at Ataturk University, and was carried out according to the guidelines of the World Medical Association Declaration of Helsinki, 2000. A verbal consent was obtained from the nurses prior to participation in the research. All the participants were informed of the purpose and design of the study. Participation in the study was voluntary.

\section{Instruments}

During data collection, a survey about communication problems between the nurse and the patient was used. The questionnaire was prepared by the researchers, in accordance with the literature ${ }^{7,11,14}$. The questionnaire consists of two parts. Part 1 includes demographic characteristics of nurses (i.e. age, gender, education level, working years in the profession, working years in ICU); and Part 2 involves a total of 13 questions (2 questions about professional characteristics of nurses and 11 questions about difficulties in patient communication and the communication problems experienced). While the difficulties experienced by the nurses in verbal and non-verbal communication were obtained through closed-ended questions (yes/no/partially), contributing factors to communication difficulties and solution suggestions were obtained by openended questions.

\section{Data collection}

After obtaining approval from the Ethics Committee, the questionnaires were administered to the nurses. The nurses had been briefly informed by the researchers on the purpose and methods of the study. The participants completed the forms within approximately 15-20 minutes.

\section{Data analysis}

For data entry and analysis, the Statistical Package for Social Sciences (SPSS Chicago, IL, USA) for Windows version 18.0 was used. Descriptive statistics (i.e. mean, standard deviation, frequency) was used to analyze study questions. The $\chi^{2}$-test was used to evaluate differences between Polish and Turkish nurses.

\section{Results}

\section{Description of study samples}

Demographic characteristics of the nurses are presented in Table 1. One hundred and two nurses participated in the study. The mean age of the nurses was 35.86 and 28.38 years, standard deviation 0.98 and 5.21 years in Poland and Turkey, respectively. Approximately $94 \%$ of the Poland sample and $76.9 \%$ of the Turkey sample were female nurses. Of the nurses in Poland, 10 (20.0\%) graduated from nursing vocational school, 14 (28.0\%) from nursing college, 13 (26.0\%) had bachelor's degree, and 13 (26\%) had master's degree. Of the nurses in Turkey, 4 (7.7\%) graduated from nursing vocational school, 6 (11.5\%) had associate's 
Table 1. Demographic characteristics of study nurses

\begin{tabular}{|c|c|c|}
\hline & $\begin{array}{l}\text { Polish } \\
\text { nurses } \\
(\mathrm{N}=50) \\
\mathrm{n}(\%)\end{array}$ & $\begin{array}{l}\text { Turkish } \\
\text { nurses } \\
(\mathrm{N}=52) \\
\mathrm{n}(\%)\end{array}$ \\
\hline Age (yrs) [mean (SD)] & $35.86(0.98)$ & $28.38(5.21)$ \\
\hline $\begin{array}{c}\text { Gender } \\
\text { Female } \\
\text { Male }\end{array}$ & $\begin{array}{l}47(94.0) \\
3(6.0)\end{array}$ & $\begin{array}{l}40(76.9) \\
12(23.1)\end{array}$ \\
\hline $\begin{array}{l}\text { Educational status } \\
\text { Nursing high school } \\
\text { Nursing college }^{\mathrm{a}} \\
\text { Associate's degree }^{\mathrm{b}} \\
\text { Bachelor's degree } \\
\text { - distance education } \\
\text { Bachelor's degree } \\
\text { Master's degree }\end{array}$ & $\begin{array}{l}10(20.0) \\
14(28.0) \\
-(0.0) \\
-(0.0) \\
13(26.0) \\
13(26.0)\end{array}$ & $\begin{array}{l}4(7.7) \\
-(0.0) \\
6(11.5) \\
3(5.8) \\
37(71.2) \\
2(3.8)\end{array}$ \\
\hline $\begin{array}{l}\text { Working years in ICU } \\
1-5 \text { years } \\
6-10 \text { years } \\
11-15 \text { years } \\
16-20 \text { years } \\
\geq 21 \text { years }\end{array}$ & $\begin{array}{l}12(24.0) \\
15(30.0) \\
6(12.0) \\
13(26.0) \\
4(8.0)\end{array}$ & $\begin{array}{l}46(88.4) \\
4(7.6) \\
2(3.8) \\
0(0.0) \\
0(0.0)\end{array}$ \\
\hline $\begin{array}{l}\text { ICU certificate } \\
\text { Yes } \\
\text { No }\end{array}$ & $\begin{array}{l}13(26.0) \\
37(74.0)\end{array}$ & $\begin{array}{l}24(46.2) \\
28(53.8)\end{array}$ \\
\hline
\end{tabular}

a There is no nursing college in Turkey; bthere is no associate's degree in Poland; 'there is no bachelor's degree-distance education in Poland; ICU = intensive care unit

degree, 40 (77\%) had bachelor's degree, and 2 (3.8\%) had master's degree. It was found that $26 \%$ and $46.2 \%$ of the nurses had an ICU certificate in Poland and Turkey, respectively.

\section{Description of the communication problems experienced by critical care nurses}

Table 2 shows distribution of the communication problems experienced by the nurses. In this study, it was determined that $46 \%$ and $42.3 \%$ of the nurses had communication problems with patients in Poland and Turkey, respectively $(\mathrm{p}<0.05)$. As shown in Table 3 , considering the nurses in the study who experienced communication issues, $32 \%$ and $73 \%$ of the nurses stated they were the cause of the problem, respectively. Clinical conditions were cited as a root cause for $76 \%$ and $98 \%(\mathrm{p}<0.05)$, while the intensive care environment was deemed responsible for $78 \%$ and $46.2 \%$ $(p<0.05)$ of the problems, respectively. Finally, patient relatives were cited as a cause of communication problems by $74 \%$ and $63 \%$ ( $p>0.05)$ of the nurses, respectively.

This survey also explored different reasons for communication problems caused by the nurses themselves. In Poland, $75 \%$ of the nurses reported that their work was not patient centered due to the lack of staff, insufficient knowledge and skills about communication, or no need to communicate with patients who were in terminal stages or unconscious. On the other hand, in Turkey, $57.8 \%$ of the nurses specified that they worked hard during the week. When the nurses' communication problems related to patient clinical conditions were examined, $97.3 \%$ and $88.2 \%$ of the nurses in Poland and Turkey, respectively, reported that patients were unconscious or had language differences. It was also found that $80 \%$ and $86.6 \%$ of the nurses in Poland and Turkey indicated that a contributing factor to communication problems were physical conditions in the ICU including overly full ICUs and difficult conditions of the building itself. Reactions of relatives to patient situation also caused communication problems (77.7\% and 64.0\% in Poland and Turkey, respectively) (Table 4).

The non-verbal communication methods that nurses used in the ICU differed between the two countries. In Poland, the nurses mostly used therapeutic touch as a non-verbal communication method,

Table 2. Distribution of communication problems experienced by nurses

\begin{tabular}{|l|l|l|l|l|}
\hline & $\begin{array}{l}\text { Polish nurses }(\mathrm{N}=50) \\
\mathrm{n}(\%)\end{array}$ & $\begin{array}{l}\text { Turkish nurses }(\mathrm{N}=52) \\
\mathrm{n}(\%)\end{array}$ & $\chi^{2}$ & $\mathrm{p}$ \\
\hline Communication problems: & & $22(42.3)$ & & \\
Yes & $23(46.0)$ & $26(50.0)$ & 8.351 & $0.015^{*}$ \\
Partially & $14(28.0)$ & $4(7.7)$ & & \\
No & $13(26.0)$ & & \\
\hline
\end{tabular}

*p $<0.05$ 
Table 3. Reasons for communication problems in nurses

\begin{tabular}{|l|l|l|l|l|}
\hline & $\begin{array}{l}\text { Polish nurses }(\mathrm{n}=50) \\
\mathrm{n}(\%)\end{array}$ & $\begin{array}{l}\text { Turkish nurses }(\mathrm{n}=52) \\
\mathrm{n}(\%)\end{array}$ & $\chi^{2}$ & $\mathrm{p}$ \\
\hline $\begin{array}{l}\text { Reason }{ }^{\text {a }} \\
\text { Nurses themselves }\end{array}$ & $16(32.0)$ & $38(73.0)$ & 17.344 & 0.000 \\
Clinical condition of patient & $38(76.0)$ & $51(98.0)$ & 32.099 & 0.000 \\
ICU environment & $39(78.0)$ & $24(46.2)$ & 14.153 & 0.001 \\
Patient relative & $37(74.0)$ & $33(63.4)$ & 3.271 & 0.195 \\
\hline
\end{tabular}

aPercentage of those answering "yes" to the question; ICU = intensive care unit

Table 4. Reasons for communication problems caused by nurses themselves, clinical condition of the patient, ICU environment and patient relatives

\begin{tabular}{|c|c|c|}
\hline & $\begin{array}{l}\text { Polish nurses }(\mathrm{N}=50) \\
\mathrm{n}(\%)\end{array}$ & $\begin{array}{l}\text { Turkish nurses }(\mathrm{N}=52) \\
\mathrm{n}(\%)\end{array}$ \\
\hline $\begin{array}{l}\text { Problems caused by nurses themselves }^{\mathbf{a}} \\
\text { Working non-patient centered due to the lack of staff } \\
\text { No need to communicate with patients who are in terminal } \\
\text { stage and unconscious } \\
\text { Inadequate knowledge and skills about communication } \\
\text { Fulfilling only physical requirements of patients due } \\
\text { to the lack of time } \\
\text { Working hard during the week } \\
\text { No motivation because of night shifts and lack of sleep }\end{array}$ & $\begin{array}{l}12(75.0) \\
12(75.0) \\
12(75.0) \\
8(50.0) \\
5(31.2) \\
4(25.0)\end{array}$ & $\begin{array}{l}19(50.0) \\
10(26.3) \\
3(7.8) \\
18(47.3) \\
22(57.8) \\
17(44.7)\end{array}$ \\
\hline $\begin{array}{l}\text { Problems caused by clinical condition of the patient } \\
\text { Unconscious patients } \\
\text { Patients with confusion or delirium } \\
\text { Patients on mechanical ventilation } \\
\text { Patients with language differences } \\
\text { Patients refusing treatment } \\
\text { Elderly patients } \\
\text { Patients with loss of sensation }\end{array}$ & $\begin{array}{l}37(97.3) \\
31(81.5) \\
28(73.6) \\
16(42.1) \\
11(28.9) \\
8(21.0) \\
2(5.2)\end{array}$ & $\begin{array}{l}34(66.6) \\
34(66.6) \\
28(54.9) \\
45(88.2) \\
40(78.4) \\
25(49.0) \\
24(47.0)\end{array}$ \\
\hline $\begin{array}{l}\text { Problems caused by ICU environment } \\
\text { More patients in one room in ICU } \\
\text { Difficult conditions of the building }\end{array}$ & $\begin{array}{l}8(80.0) \\
2(20.0)\end{array}$ & $\begin{array}{l}2(13.3) \\
13(86.6)\end{array}$ \\
\hline $\begin{array}{l}\text { Problems caused by patient relatives }{ }^{\mathbf{a}} \\
\text { Relative reactions to patient's situation } \\
\text { Relatives have negative attitude towards treatment and staff }\end{array}$ & $\begin{array}{l}21(77.7) \\
6(22.3)\end{array}$ & $\begin{array}{l}16(64.0) \\
9(36.0)\end{array}$ \\
\hline
\end{tabular}

aPercentages calculated on the basis of ' $n$ '

Table 5. Non-verbal communication methods the nurses use in the ICU

\begin{tabular}{|l|l|l|l|l|}
\hline & $\begin{array}{l}\text { Polish nurses }(\mathrm{N}=50) \\
\mathrm{n}(\%)\end{array}$ & $\begin{array}{l}\text { Turkish nurses }(\mathrm{N}=52) \\
\mathrm{n}(\%)\end{array}$ & $\chi^{2}$ & $\mathrm{p}$ \\
\hline $\begin{array}{l}\text { Non-verbal methods: } \\
\text { Facial expression }\end{array}$ & $32(64.0)$ & $47(90.4)$ & 10.161 & $0.001^{*}$ \\
$\begin{array}{l}\text { Eye contact } \\
\text { Therapeutic touch }\end{array}$ & $38(76.0)$ & $44(84.6)$ & 1.200 & 0.273 \\
\hline
\end{tabular}

$* \mathrm{p}<0.05$ 
whereas in Turkey, the nurses used facial expressions ( $80 \%$ vs. $90.4 \%$; $\mathrm{p}<0.05$ both). When we looked at the nurses' views about the effect of non-verbal communication, 55.1\% of the nurses in Poland reported that patients felt safer and their physiological comfort increased when nurses used non-verbal communication. Similarly, in Turkey, $51.2 \%$ of the nurses stated that non-verbal communication was important for the treatment process (Table 5).

\section{Discussion}

In normal communication, many barriers may arise from the intrinsic factors that constitute the communication process and the environment in which communication occurs. Barriers and difficulties in communication may be caused by the individuals, environment, or other factors ${ }^{15-17}$. In the present study, examining the communication problems caused by the nurses themselves, the breakdown of working patientcentered care due to the insufficient number of nurses was observed as a primary factor in Poland, and as secondary in Turkey. Similarly, Karadağ and Taşç ${ }^{18}$ stated that factors such as working in shifts and being on single guard duty increased the risk of burnout and negatively affected the care provided by nurses. In the review discussing critical care standards, Bray et al. ${ }^{19}$ underlined the necessity of staffing ICUs with one nurse for every two patients, and one nurse for each patient on a ventilator. However, since it is not possible to provide these conditions in many ICUs, communication difficulties may be caused by the insufficient number of nurses. The critical care nurses in Turkey stated that the primary reason for self-driven communication problems was the intensity of their work throughout the week. Some studies in the literature report that the workload in ICUs was the most important reason for the stress experienced by nurses ${ }^{20}$. Work-related stress factors, such as heavy workload, burnout and the wish to avoid attachment to patients who may die, are reasons for the lack of communication $^{2}$. Also, exposure to high level of stress arising from the care process itself exerts a very real impact on the psychological and physiological well-being of ICU staff, increases the staff's burnout level and shift patterns, and influences the quality of care and communication with patients ${ }^{21,22}$. The present study findings are consistent with the literature.
Nurses may ignore the communicational needs of patients due to excessive number of patients and stressful intensive working conditions ${ }^{2}$. In this study, it was determined that $50 \%$ of the ICU nurses in Poland and $47.3 \%$ in Turkey could only meet physical needs of their patients due to insufficient time and heavy workload. In their study examining the practices of nurses working in surgical ICUs and focused on the care of dying patients, Özdemir and Çelik ${ }^{23}$ also indicated that the practices of nurses were mostly aimed at meeting their physiological rather than psychosocial needs. In a study conducted in 100 patients and 79 nurses in an ICU, $50 \%$ of patients associated receiving treatment in the ICU with dying and 69\% stated that the nurses neglected them and did not talk to or understand them ${ }^{24}$. In a study conducted by Baker and Melby ${ }^{25}$, it was found that nurses spent only 5 percent of their time communicating with their patients, with the interactions consisting primarily of explanations and orientation information. Based on the results of this study, it can be considered that nurses ignore patient communication requirements and only deal with their physical care, due to the insufficiency of nursing staff and time, and heavy workloads. From this point of view, it becomes crucial for nurses to focus not only on the physical needs of patients but also on psychosocial needs of patients hospitalized in the ICU.

Examining the reasons for communication difficulties from the aspect of clinical conditions of ICU patients, difficulties were experienced with unconscious patients by a great majority $(97.3 \%)$, with patients in confusion/delirium by $81.5 \%$, and with mechanically ventilated patients by $73.6 \%$ of the critical care nurses in Poland. In Turkey, the nurses experienced communication difficulties with patients with language differences (88.2\%), with patients refusing treatment $(78.4 \%)$ and with patients with unconsciousness, confusion or delirium (66.6\%). Since unconscious patients are unable to give feedback on patient-nurse relationships, nurses considered them as the patient group most difficult to communicate with ${ }^{15}$. An article reviewing the relevant literature states that, even when nurses have communication training and skills, their communication with patients is still weak ${ }^{2}$. This is probably because of the high level of stress, being excessively concerned with physical care and technology, and specific personality types ${ }^{2}$. Despite the nurses' lack of attention, Lawrence ${ }^{26}$ established that 
100 unconscious patients heard, perceived and showed emotional responses, even though the healthcare professionals assumed that the patients were not even aware. Therefore, the author emphasizes the necessity of establishing verbal communication with unconscious patients.

Sedation, fatigue, confusion, delirium, neurological diseases and critical diseases constitute other clinical conditions that cause deterioration of patient communication skills and produce communication difficul$\operatorname{ties}^{27}$. In this study, confusion or delirium in ICU patients was indicated as a secondary reason in Poland and a tertiary reason in Turkey for communication difficulties. In a study by Russell ${ }^{13}$, patients reported that anxiety and other psychological problems were particularly related to poor communication between the staff and the patients. In that respect, use of communication strategies with patients in delirium and orientation of patients by nurses are important factors in the prevention and treatment of delirium ${ }^{28}$.

In the present study, $78.4 \%$ of the critical care nurses in Turkey stated that they had communication problems with patients refusing treatment. Patients may express their anger, directly or indirectly, by refusing treatment, care or cooperation, by making frequent requests, by using verbal interferences or vitriols, or by making constant complaints ${ }^{29,30}$. Doğan et al..$^{29}$ determined that nurses encountered behaviors expressing either direct or indirect anger, such as hospitalized patient yelling (87.4\%) or refusing treatment and care (88.4\%).

Intubation represents a very sensitive balance between life and death for patients, and intubated patients lose a great part of their communication skills ${ }^{14,31,32}$. In this study, the ICU nurses in both countries indicated the intubated group of patients as a source of communication problems (Poland 73.6\% and Turkey 54.9\%). Rotondi et al. ${ }^{33}$ asked 75 ICU patients to recall their experiences while being mechanically ventilated for more than 48 hours and found that $65 \%$ of their patients had communication difficulties. However, other researchers report that only $9 \%$ of the intubated ICU patients were completely unable to communicate with healthcare professionals and that 91\% were able to communicate non-verbally by nodding, writing, or gestures ${ }^{34}$. Patak et al. ${ }^{6}$ asked $29 \mathrm{pa}^{-}$ tients about their experience regarding their communication with healthcare providers while they were intubated; 19 (66\%) patients reported that healthcare providers helped them communicate their needs, 7 (24\%) patients reported that care providers were unable to help them communicate their needs, and 3 (10\%) patients reported that care providers did nothing to help them communicate. These results show that many nurses communicate extremely poorly with patients, despite knowing that effective communication is important. These findings are similar to those recorded in the present study.

Although things differ from one hospital to another, physical environment in many ICUs exhibits many 'workplace stressors' including unpleasant lighting, annoying noise, disorganized equipment, and overcrowding ${ }^{20}$. In this study, considering the reasons for communication difficulties caused by physical conditions in ICUs, $80 \%$ of the nurses in Poland stated that ICUs were overcrowded, while $86.6 \%$ of the nurses in Turkey indicated that physical conditions in ICUs were inadequate for proper patient care (i.e. monitorization, noise, excessive stimuli, lack of windows, curtain/screen). In their study regarding the views of patients concerning ICUs, Tunçay and Uçar ${ }^{35}$ stated that $32.1 \%$ of patients complained of being in a strange environment, $27.4 \%$ of the number of beds in the environment, $26.4 \%$ of the noise caused by machines in the environment, and $25.5 \%$ of witnessing medical interventions made on other patients. Even though there were differences between the two countries in terms of communication problems caused by the ICU environment, the results of this study showed a similarity with the literature. According to all these results, it could be considered that the risk of developing delirium or confusion in the patient increased, and the nurses experienced communication difficulties with these patient groups due to the reasons such as excessive amount of noise and stimuli in the ICU environment, as well as the unhelpful physical conditions of the ICU environment.

Communication means talking and/or signaling non-verbally while simultaneously listening and/or observing non-verbal signals ${ }^{4}$. Patients in an ICU for a period exceeding 24 hours have between 41 and 165 direct interactions with other, usually unfamiliar peo$\mathrm{ple}^{36}$. In ICU circumstances, verbal communication plays a smaller role in comparison to non-verbal signaling when messages are conveyed. Nurses, therefore, have to pay close attention to the patient efforts to 
communicate non-verbally ${ }^{4}$. Nurses in this study used therapeutic touch and facial expressions to communicate non-verbally with patients in Poland and Turkey ( $80 \%$ and $90.4 \%$, respectively). Moreover, the nurses in this study described some verbal communication problems with patients on mechanical ventilators in ICUs. Happ et al. ${ }^{37}$ determined that nodding, lip-reading, gestures and writing were among the primary nonverbal communication methods that were used by the patients who were on mechanical ventilators in ICUs. Likewise, Johansson ${ }^{11}$ examined nurse-patient communication throughout ventilation and found that $54 \%$ of the patients preferred body language, $32.2 \%$ writing, and $23 \%$ yes-no questions for communication. In order to support patients in ICUs who are coping with anxiety, nursing non-verbal behaviors such as making eye contact, using therapeutic touch and expressive body language, keeping in constant communication and offering explanations before treatment are the key practices which will enable the patient to adjust to the ICU and have satisfying communication ${ }^{38,39}$.

\section{Study limitations}

The study was conducted in only one hospital each in Poland and Turkey, and the study sample reflects only one area in Poland and Turkey. Therefore, our findings cannot be generalized to all critical care nurses.

\section{Conclusion}

In this study, it was observed that the ICU nurses in both countries experienced similar difficulties in patient communication. When the nurses were asked about the most important problems experienced in communication and what solutions they could suggest, the nurses in both countries substantially stated that it was required to increase the number of nurses in ICUs since staffing was insufficient. The study also determined that the nurses experienced communication difficulties because of being able to meet only the physical needs of patients due to the intensive volume of work and lack of time. A final set of communication difficulties arose when caring for unconscious patients, patients with delirium, intubation or language differences, and with patients refusing treatment. Based on these results, it is recommended that nurses working in ICUs participate in communication certificate pro- grams. Nurses should also be encouraged to be receptive to the opinions of patients about communication problems, as well as patient suggestions for solutions. A communication board may be effective in decreasing frustration and in facilitating communication. Efficient and accurate communication with the patients in ICUs enables nurses to examine the patient as a whole and provide a quality nursing care. Since patient-nurse communication contributes to both the physiological and psychological recovery of patients, it is an important instrument of nursing treatment, and has the potential to increase the satisfaction of both healthcare professionals and patients.

\section{Acknowledgments}

The authors would like to thank the critical care nurses who agreed to participate in the study and for their cooperation.

\section{References}

1. Hemsley BJ, Sigafoos J, Balandin S, Forbes R, Taylor C, Green VA, et al. Nursing the patient with severe communication impairment. J Adv Nurs. 2001;35:827-35, http://dx.doi. org/10.1046/j.1365-2648.2001.01920.x

2. Llenore E, Ogle KR. Nurse-patient communication in the intensive care unit: a review of the literature. Aust Crit Care. 1999;12:142-5.

3. Magnus VS, Turkington L. Communication interaction in ICU - patient and staff experiences and perceptions. Intensive Crit Care Nurs. 2006;22:167-80, http://dx.doi.org/10.1016/j. iccn.2005.09.009

4. Meriläinen M, Kyngäs $H$, Ala-Kokko T. Patients' interactions in an intensive care unit and their memories of intensive care: a mixed method study. Intensive Crit Care Nurs. 2013;29:78-87, http://dx.doi.org/10.1016/j.iccn.2012.05.003

5. Antai-Otong D. Nurse-Client Communication. A Life Span Approach. USA: Jones and Barlett Publishers Inc.; 2007.

6. Patak L, Gawlinski A, Fung NI, Doering L, Berg J. Patients' reports of health care practitioner interventions that are related to communication during mechanical ventilation. Heart Lung. 2004;33:308-21,http://dx.doi.org/10.1016/j.hrtlng.2004.02.002

7. Alasad J, Ahmad M. Communication with critically ill patients. J Adv Nurs. 2005;50:356-62. doi: 10.1111/j.1365$-2648.2005 .03400 . x$.

8. Bergbom-Engberg I, Haljamae H. The communication process with ventilator patients in the ICU as perceived by the nursing staff. Intensive Crit Care Nurs. 1993;9:40-7, http://dx.doi. org/10.1016/0964-3397(93)90008-L 
9. Hall DS. Interactions between nurses and patients on ventilators. Am J Crit Care. 1996;5:293-7.

10. Happ MB, Garrett K, DiVirgilio TD, Tate J, George E, Houze $\mathrm{M}$, et al. Nurse-patient communication interactions in the intensive care unit. Am J Crit Care. 2011;20:e28-40, http:// dx.doi.org/10.4037/ajcc2011433

11. Johansson GW. Communication between nurse and patient during ventilator treatment: patient reports and $\mathrm{RN}$ evaluations. Intensive Crit Care Nurs. 2001;17:29-39, http://dx.doi. org/10.1054/iccn.2000.1547

12. Patak L, Wilson-Stronks A, Costello J, Kleinpell RM, Henneman EA, Person C, et al. Improving patient-provider communication: a call to action. J Nurs Adm. 2009;39:372-6, http://dx.doi.org/10.1097/NNA.0b013e3181b414ca

13. Russell S. An exploratory study of patients' perceptions, memories and experiences of an intensive care unit. J Adv Nurs. 1999;29:783-91, http://dx.doi.org/10.1046/j.1365-2648. 1999.00953.x

14. Yava A, Koyuncu, A. [Our communication experiences with the intubated patients: case reports]. J Gülhane Med. 2006;48: 175-9. (in Turkish)

15. Hagland MR. Nurse-patient communication in intensive care: a low priority? Intensive Crit Care Nurs. 1995;11:111-5, http: //dx.doi.org/10.1016/S0964-3397(95)82022-1

16. Uyer G. [Patient communication and its importance for patient]. Turk Clin J Med Ethics. 2000;8:90-4. (in Turkish)

17. Arda H, Ertem M, Baran G, Durgun Y. [The opinions of doctor and nurses who worked in Dicle University regarding patient communication]. Florence Nightingale J Nurs. 2007;15: 68-74. (in Turkish)

18. Karadağ S, Taşçı S. [The factors affecting the nursing care given by the nurses working in Kayseri State Hospital]. J Health Sci. 2005;14:13-21. (in Turkish)

19. Bray K, Wren I, Baldwin A, Ledger US, Gibson V, Goodman $\mathrm{S}$, et al. Standards for nurse staffing in critical care units determined by the British Association of Critical Care Nurses, the critical care networks national nurse leads, Royal College of Nursing Critical Care and In-flight Forum. Nurs Crit Care. 2010;15:109-11, http://dx.doi.org/10.1111/j.1478-5153.2010. 00392.x

20. Alameddine M, Dainty KN, Deber R, Sibbald WJ. The intensive care unit work environment: current challenges and recommendations for the future. Crit Care. 2009;24:243-8, http:// dx.doi.org/10.1016/j.jcrc.2008.03.038

21. Donchin Y, Seagull FJ. The hostile environment of the intensive care unit. Curr Opin Crit Care. 2002;8:316-20.

22. McVicar A. Workplace stress in nursing: a literature review. J Adv Nurs. 2003;44:633-42, http://dx.doi.org/10.1046/j.0309$-2402.2003 .02853 . x$

23. Özdemir Z, Çelik SŞ. [Practices of the nurses working in surgical intensive care units for the patients who are in death process]. Turk Clin J Nurs. 2010;2:32-41. (in Turkish)
24. Alaca Ç, Yiğit R, Özcan A. [Comparison of nurses' and patients' opinions about their experiences during the disease process of inpatients in the intensive care unit]. J Psychiatr Nurs. 2011;2:69-74. (in Turkish)

25. Baker C,Melby V. An investigation into the attitudes and practice of intensive care nurses towards verbal communication with unconscious patients. J Clin Nurs. 1996;5:185-92, http: //dx.doi.org/10.1111/j.1365-2702.1996.tb00248.x

26. Lawrence M. The unconscious experience. Am J Crit Care. 1995;4:227-32.

27. Happ MB. Communicating with mechanically ventilated patients: state of the science. Am Assoc Crit Care Nurs Clin Issues. 2001;12:247-58.

28. Schuurmans MJ, Duursma SA, Shortridge-Baggett LM. Early recognition of delirium: review of the literature. J Clin Nurs. 2001;10:721-9, http://dx.doi.org/10.1111/j.1365-2702.2001. 00548.x

29. Doğan S, Güler H, Kelleci M. [Nurses' approaches against angry patients]. Cumhuriyet Univ J Nurs. 2001;5:26-32. (in Turkish)

30. Şahin H. [Anger and theoretical basis of anger control]. J Burdur Educ Fac. 2005;6:1-22. (in Turkish)

31. Grap MJ, Blecha T,Munro C.A description of patients'report of endotracheal tube discomfort. Intensive Crit Care Nurs. 2002; 18:244-9, http://dx.doi.org/10.1016/S0964339702000654

32. Menzel LK. Factor related to the emotional responses of intubated patients to being unable to speak. Heart Lung. 1998;27: 245-52, http://dx.doi.org/10.1016/S0147-9563(98)90036-X

33. Rotondi AJ, Chelluri L, Sirio C, Mendelsohn A, Schulz R, Belle $\mathrm{S}$, et al. Patients' recollections of stressful experiences while receiving prolonged mechanical ventilation in an intensive care unit. Crit Care Med. 2002;30:746-52.

34. Yeh SH, Lee LN, Ho TH, Chiang MC, Lin LW. Implications of nursing care in the occurrence and consequences of unplanned extubation in adult intensive care units. Int J Nurs Stud. 2004;41:255-62, http://dx.doi.org/10.1016/S0020-7489 (03)00136-6

35. Tunçay GY, Uçar H. [Opinions of patients on physical environmental features of intensive care units]. Hacettepe Univ Fac Health Sci Nurs J. 2010;3:33-46. (in Turkish)

36. Meriläinen M, Kyngäs H, Ala-Kokko T. 24-hour intensive care: an observational study of an environment and events. Intensive Crit Care Nurs. 2010;26:246-53, http://dx.doi.org/ 10.1016/j.iccn.2010.06.003

37. Happ MB, Tuite P, Dobbin K, Divirgilio-Thomas D, Kitutu J. Communication ability, method, and content among nonspeaking nonsurviving patients treated with mechanical ventilation in the intensive care unit. Am J Crit Care. 2004;13: 210-20.

38. Terzi B, Kaya N. [Nursing care in intensive care patients]. J Turk Soc Intensive Care. 2011;1:21-5. (in Turkish)

39. Brüne M. Nonverbal behaviour in psychopathology: why we need to revive the interpersonal dimension in clinical psychiatry. Acta Clin Croat. 2014;53 Suppl 1:79-80. 


\section{Sažetak}

\section{PROBLEMI POVEZANI S KOMUNIKACIJOM IZMEĐU MEDICINSKIH SESTARA I BOLESNIKA U JEDINICI INTENZIVNOG LIJEČENJA: PRIMJERI IZ POLJSKE I TURSKE}

\section{Y. Yaman Aktas, M. Nagórska i N. Karabulut}

Cilj ovoga istraživanja bio je utvrditi probleme povezane s komunikacijom između medicinskih sestara i bolesnika u jedinici intenzivnog liječenja (JIL), s naglaskom na razlikama između Poljske i Turske. Ovo opisno istraživanje provedeno je na Kirurškoj JIL, Lwowska Hospital u Poljskoj i u JIL, Training and Research Hospital u Turskoj. U istraživanje je bilo uključeno 50 medicinskih sestara u intenzivnoj skrbi iz Poljske i 52 medicinske sestre u intenzivnoj skrbi iz Turske. Podaci o bolesnicima prikupljeni su pomoću upitnika koji su pripremili sami istraživači. U ovom istraživanju je $46 \%$ medicinskih sestara iz Poljske i 42,3\% medicinskih sestara iz Turske izjavilo da imaju probleme u komunikaciji s bolesnicima. Također je utvrđeno da medicinske sestre u Poljskoj većinom primjenjuju terapijski dodir za neverbalnu komunikaciju (80\%), dok medicinske sestre u Turskoj najviše primjenjuju određene izraze lica (90,4\%). Medicinske sestre u JIL iz obiju zemalja imale su slične poteškoće u komunikaciji s bolesnicima. Preporuča se omjer bolesnika i medicinskih sestara u JIL planirati prema standardima intenzivne skrbi.

Ključne riječi: Jedinice za intenzivnu skrb; Sestra-bolesnik, odnosi; Komunikacija 